\title{
Joint analysis for oil content and TRAP markers in elite castor bean strains
}

\author{
K.S. Simões ${ }^{1}$, S.A. Silva ${ }^{1}$, E.L. Machado ${ }^{1}$, L.A. dos Santos ${ }^{1}$, \\ C.R. Filadelfo ${ }^{1}$ and C.S. Linge ${ }^{2}$ \\ ${ }^{1}$ Genetic Improvement and Biotechnology Unit, Center for Agricultural, \\ Environmental and Biological Sciences, Federal University of Recôncavo da \\ Bahia, Cruz das Almas, BA, Brasil \\ ${ }^{2}$ Department of Plant and Environmental Sciences, Clemson University, \\ Clemson, SC, USA
}

Corresponding author: K.S. Simões

E-mail: karinesimoes01@hotmail.com

Genet. Mol. Res. 19 (4): gmr18688

Received August 04, 2020

Accepted October 21, 2020

Published November 30, 2020

DOI http://dx.doi.org/10.4238/gmr18688

ABSTRACT. The demand for quality vegetable oil, such as castor
oil, has been increasing significantly due to its great applicability in
the cosmetic and industrial sector, especially with the advent of
biodiesel. Castor bean produces a non-edible oil, with unique
chemical properties, which makes it potentially useful for the
production of cosmetics, aircraft lubricants and biodiesel. Breeding
programs aimed at increasing the oil content in castor bean seeds are
of paramount importance to meet the requirements of this market. In
view of the above, we examined the genetic variability of elite castor
bean strains through joint analysis of the oil content trait and TRAP
(Target Region Amplification Polymorphism) molecular markers.
This analysis was performed using the means for seed oil content of
40 elite castor bean strains, developed by the breeding program of the
Genetic Improvement and Biotechnology Unit of the Federal
University of Recôncavo da Bahia, together with genotyping of this
population by means of 44 combinations of TRAP primers (fixed and
arbitrary primers). Genetic dissimilarity between the strains was
calculated through the Gower dissimilarity index, using the UPGMA
clustering method. The means for oil content rangeed from 39.10
(UFRB 36) to 55.39\% (UFRB 209), demonstrating that there is 
genetic variability among the strains. The 44 TRAP combinations enabled the identification of 380 fragments, $61 \%$ of which were polymorphic. The joint analysis formed three clusters, showing that there is genetic divergence among these elite strains. Therefore, joint analysis of the seed oil content trait and TRAP markers is efficient to evaluate the genetic dissimilarity in castor bean strains, demonstrating potential for the breeding program of the species.

Key words: Biodiesel; Genetic divergence; Ricinus communis; Gower's algorithm

\section{INTRODUCTION}

Castor bean (Ricinus communis), belonging to the Euphorbiaceae family, has a wide geographical distribution in the world. In tropical and subtropical climates, this crop is present in approximately 15 countries. In Brazil, the regions with effective areas of cultivation, yield and production are: Northeast (Piauí, Ceará, Pernambuco and Bahia), Mid-West (Mato Grosso), Southeast (Minas Gerais), North/Northeast, Mid-South (CONAB, 2017). It is an oilseed crop that can be exploited in the Brazilian semi-arid region, which generates the possibility of occupation and income for family farmers in the region (Cavalcanti et al., 2005).

Being an oilseed crop, the main product extracted from castor bean is the oil of its seeds, considered noble and of great industrial versatility. The distinction of castor oil is due to its composition, with a large amount of ricinoleic acid, on average about $90 \%$ (Torres, 2006).

The castor bean production chain is already well established, due to its great versatility and to the economic value of the oil extracted from its seeds (Madalena et al., 2017). However, biodiesel production is still little representative, despite its positive aspects, adaptability and introduction in family farming as an alternative, especially in the Northeast region (Madalena et al., 2017). Castor oil has a high price, due to the low supply and high demand. Castor oil is used in several areas as raw material, especially in the castor oil chemical industry. In castor bean cultivation, with $87 \%$ of the global grain production, India occupies the first place in the ranking, followed by Mozambique, China and Brazil (Faostat, 2017). The main importers of castor oil are France, Germany, United States, Japan, China, the Netherlands and Thailand, which use this raw material in various products in industries (Cunha et al., 2017). According to Conab (2017), the estimated national production of castor bean in the 2016/2017 season was 15,200 tons. In the Brazilian production, approximately more than $90 \%$ comes from the Northeast region (IBGE, 2017). According to Faostat (2017), Brazilian production has an average yield of $0.59 \mathrm{t} / \mathrm{ha}^{-1}$.

Also, castor bean has great genetic variability, which is easily observed in botanical and agronomic characteristics (Silva et al., 2017). However, these characteristics, especially quantitative ones, are influenced by the environment and epistasis. Thus, the genetic variability of castor bean should also be evaluated by DNA polymorphism, ruling out any environmental influence on the genome.

The castor bean breeding program of the Center for Genetic Improvement and Biotechnology (NBIO) of the Federal University of Recôncavo da Bahia - (UFRB), through 
controlled hybridizations and generation of self-fertilized populations, has developed elite strains aiming to release new cultivars in order to meet market demand. As part of the process, these elite strains in the present study were evaluated for seed oil content and genetic variability at the DNA level by molecular markers.

Molecular markers are fundamental tools in several studies. In addition to enabling the characterization of germplasm, they can also be used as a tool for studies on genetic divergence between individuals, within and between populations or related species, enabling the evaluation of a high number of genotypes in the short term, and have a high degree of polymorphism, besides not being influenced by the environment (Souza et al., 2008). One of its examples is the molecular marker TRAP.

The TRAP marker is based on the combination of a fixed primer, a sequence designed using Expressed Sequence Tags (ESTs), and an arbitrary primer. The fixed primer is covered in a given region expressed in the genome during the PCR reaction, and the polymorphism generated by the combination of the two primers will be associated with a specific gene (Hu and Vick, 2003). The TRAP marker amplifies different regions, has the advantage of being a simple technique, besides providing high yield and reproducibility (Poczai et al., 2013).

TRAP markers were initially developed for sunflower DNA samples (Hu and Vick, 2003) and have been used in several other species.

Morpho-agronomic characteristics and molecular markers can be used together to study genetic variability. The joint analysis of quantitative and qualitative variables is a potential more complete indicator of the variability existing among the species, but few studies have used this strategy. This is probably due to the lack of knowledge about the statistical techniques that enable this approach, the lack of free software to analyze these data together, as well as the tendency of researchers to give more importance to those variables directly related to characters worked in breeding programs (Gonçalves et al., 2008).

The technique that enables simultaneous analysis of quantitative and qualitative data was proposed by Gower (1971). This method allows distance matrix values to be between 0 and 1, regardless of the number of variables, as a database for standardization (Crossa and Franco, 2004), which facilitates the construction of a dendrogram (Mason et al., 2005). Some experiments using this approach have been reported in studies with Pineapple sp. L. (Merr) (Machado et al., 2011), Carica papaya (Ramos et al., 2012), Passiflora (Machado et al., 2015), Jatropha curcas (Pestana-Caldas et al., 2016) and R. communis L. (Silva et al., 2017).

Joint analysis for seed oil content and TRAP markers in elite castor bean strains is still unprecedented. In view of the above, we assessed the genetic diversity among elite strains of $R$. communis regarding the seed oil content trait together with TRAP molecular markers, aiming to assist the NBIO-UFRB breeding program of the species.

\section{MATERIAL AND METHODS}

\section{Plant material}

Forty elite strains of castor bean were developed by the breeding program of the Genetic Improvement and Biotechnology Unit of the Federal University of Recôncavo da 
Bahia - NBIO/UFRB, in the city of Cruz das Almas, Bahia, Brazil. The strains were obtained from crosses between the following parents: BRS Nordestina, Sipeal, EBDA MPA-17, Mirante and Paraguaçu.

The castor bean strains of UFRB were developed by NBIO, adopting the following procedures: the first segregating population (F2), obtained from the self-fertilization of the fixed population (F1) was derived from controlled hybridizations between the parents: BRS 149 Nordestina, BRS 188 Paraguaçu, EBDA MPA 17, Mirante 10 and Sipeal 28 performed between 2005 and 2007. The segregating and advanced populations (F2, F3, F4, F5 and F6) were conducted by self-fertilization between 2007 and 2012 by the SSD (Single Seed Descent) method, with minor modifications. Three seeds were planted per hole for subsequent thinning and there were four statistical replicates of each genetic constitution, arranged in randomized blocks to monitor the analyses of performance and variability of the individuals in each generation, until reaching a high level of homozygosis, totaling 240 strains, maintained under field conditions considering four plants per strain, at spacing of 3 $\mathrm{m} \times 1 \mathrm{~m}$, and also maintained under cooled chamber conditions at $45 \%$ humidity and temperature of $8{ }^{\circ} \mathrm{C}$. These homozygous strains were characterized in the field to identify the phenotypic profile. Castor bean strains were evaluated using phenotypic traits (qualitative descriptors and quantitative traits). The study population corresponds to 240 strains developed by NBIO/UFRB with a high level of homozygosis.

The 40 elite strains were obtained from advanced populations $\mathrm{F}_{5}: \mathrm{F}_{6}$ composed of the 240 strains that were subjected to approximately $21 \%$ selection pressure on the performance of morpho-agronomic traits. The genotypes were selected considering the traits of greatest interest for selection (seed oil content, vegetative cycle, plant height, number of seeds and seed weight).

The 40 varieties are not yet publicly available; four of them are indicated as potential cultivars that meet the DHS criteria (distinguishability, homogeneity and stability) in the evaluated regions and that are in the process of being registered with the Ministry of Agriculture, Livestock and Food Supply. Their cultivation is expected to occur only after the registry; however, some of them are being cultivated in a demonstrative area in Castro Alves and Morro do Chapéu, both in Bahia.

The developed varieties are in the phase of registration, resulting from the selection of 20 candidates for cultivars that were tested in trials of Value for Cultivation and Use (VCU) in the regions of Irecê, Iraquara (Semi-arid region), Cruz das Almas (Recôncavo) and Alagoinhas (Coastline) of Bahia, evaluated for DHS, and four cultivars that are in the process of registration at MAPA were selected.

The municipality of Cruz das Almas is located at $12^{\circ} 40^{\prime} 19^{\prime \prime}$ South latitude, $39^{\circ} 06^{\prime}$ 23" Longitude west of Greenwich and at an average altitude of $220 \mathrm{~m}$. The climate is subhumid, with average annual rainfall of $1170 \mathrm{~mm}$, varying between 900 and $1300 \mathrm{~mm}$, with the wettest months from March to August and driest months from September to February. The average annual temperature is $24.1^{\circ} \mathrm{C}$. The soil of the experimental field is classified as Latossolo Amarelo distrófico (Oxisol), with moderate A horizon and sandy clay loam texture.

The breeding method used to conduct populations was SSD (Single Seed Descent) up to the advanced generation F6, constituting a high degree of homozygosis in this generation. This method enabled the individual selection of plants belonging to the advanced population (F6). From a total of 240 strains, 40 were selected (Table 1). This 
selection took into account the morphological characters, based on individuals that showed the best means for number and weight of fruits per plant, number and weight of seeds per plant, height and flowering, with higher index for selection of seed oil content.

Table 1. List of the 40 elite castor bean strains used for the analysis of the polymorphism of Target Region Amplification Polymorphism - TRAP markers.

\begin{tabular}{|c|c|}
\hline Strain & Genealogy \\
\hline UFRB5 & Nordestina BRS149 / EBDA MPA 17 \\
\hline UFRB6 & Nordestina BRS149 / EBDA MPA 17 \\
\hline UFRB28 & Nordestina BRS149 / EBDA MPA 17 \\
\hline UFRB29 & Nordestina BRS149 / EBDA MPA 17 \\
\hline UFRB36 & Nordestina BRS149 / EBDA MPA 17 \\
\hline UFRB43 & Nordestina BRS149 / EBDA MPA 17 \\
\hline UFRB45 & Nordestina BRS149 / EBDA MPA 17 \\
\hline UFRB55 & Nordestina BRS149 / EBDA MPA 17 \\
\hline UFRB65 & Nordestina BRS149 / EBDA MPA 17 \\
\hline UFRB67 & Nordestina BRS149 / EBDA MPA 17 \\
\hline UFRB117 & Paraguaçu BRS188 / EBDA MPA 17 \\
\hline UFRB118 & Paraguaçu BRS188 / EBDA MPA 17 \\
\hline UFRB119 & Paraguaçu BRS188 / EBDA MPA 17 \\
\hline UFRB121 & Paraguaçu BRS188 / EBDA MPA 17 \\
\hline UFRB128 & Paraguaçu BRS188 / EBDA MPA 17 \\
\hline UFRB129 & Paraguaçu BRS188 / EBDA MPA 17 \\
\hline UFRB144 & Paraguaçu BRS188 / Sipeal 28 \\
\hline UFRB176 & EBDA MPA 17 / Mirante 10 \\
\hline UFRB181 & EBDA MPA 17 / Mirante 10 \\
\hline UFRB183 & EBDA MPA 17 / Mirante 10 \\
\hline UFRB186 & EBDA MPA 17 / Mirante 10 \\
\hline UFRB195 & EBDA MPA 17 / Sipeal 28 \\
\hline UFRB198 & EBDA MPA 17 / Sipeal 28 \\
\hline UFRB205 & EBDA MPA 17 / Sipeal 28 \\
\hline UFRB209 & EBDA MPA 17 / Sipeal 28 \\
\hline UFRB214 & EBDA MPA 17 / Sipeal 28 \\
\hline UFRB223 & EBDA MPA 17 / Sipeal 28 \\
\hline UFRB229 & EBDA MPA 17 / Sipeal 28 \\
\hline UFRB230 & EBDA MPA 17 / Sipeal 28 \\
\hline UFRB231 & EBDA MPA 17 / Sipeal 28 \\
\hline UFRB232 & EBDA MPA 17 / Sipeal 2817 \\
\hline UFRB235 & EBDA MPA 17 / Sipeal 28 \\
\hline UFRB237 & EBDA MPA 17 / Sipeal 28 \\
\hline UFRB240 & EBDA MPA 17 / Sipeal 28 \\
\hline UFRB249 & Mirante 10 / Sipeal 28 \\
\hline UFRB250 & Mirante 10 / Sipeal 28 \\
\hline UFRB252 & Mirante 10 / Sipeal 28 \\
\hline UFRB256 & Mirante 10 / Sipeal 2817 \\
\hline UFRB259 & Mirante 10 / Sipeal 2817 \\
\hline UFRB265 & Mirante 10 / Sipeal 28 \\
\hline
\end{tabular}

The experiment was conducted in a randomized block design with four replicates, one plant representing each plot, in an experimental area of NBIO/UFRB, located in the city of Cruz das Almas, Bahia, Brazil.

The area for installing the experiment was properly tilled, with plowing and harrowing. From soil analysis, acidity was corrected and, subsequently, fertilization was performed in the planting hole, with doses of $20 \mathrm{~kg} \cdot \mathrm{ha}^{-1}$ of $\mathrm{N}, 80 \mathrm{~kg} \cdot \mathrm{ha}^{-1}$ of P and $40 \mathrm{~kg} \cdot \mathrm{ha}^{-1}$ of K. Planting was done by direct seeding in the field, using three seeds per hole, with subsequent thinning. The spacing used was $3 \mathrm{~m}$ between rows and $1 \mathrm{~m}$ between plants. 
Approximately 30 days after planting, manual thinning was performed, leaving the most vigorous plant per hole.

\section{Quantification of seed oil content}

Seed oil content (SOC), in percentage, was quantified at the Advanced Laboratory of Chemical Technology of Embrapa Cotton located in Campina Grande - PB. This procedure was performed using the Nuclear Magnetic Resonance - NMR technique, a nondestructive method, in the instrument MQA Oxford 7005 with a $0.47 \mathrm{~T}$ electromagnet. To optimize the NMR method, the samples were kept for 24 hours in a controlled environment with temperature of $20{ }^{\circ} \mathrm{C}$. The result of the spectra was obtained using a probe with a cylindrical acrylic tube, where the seeds were placed and, after 18 seconds, the oil contents were read in the computer coupled to the device.

\section{DNA extraction}

Prior to extraction, castor bean leaves were disinfected in $20 \%$ sodium hypochlorite solution, rinsed with plenty of distilled water and stored in an ultra-freezer at $-80{ }^{\circ} \mathrm{C}$. DNA extraction was performed according to the protocol described by Doyle and Doyle (1990). Approximately $300 \mathrm{mg}$ of plant tissue were macerated in mortar in the presence of liquid nitrogen. Then, the macerate was transferred to $2-\mathrm{mL}$ microtubes, and $700 \mu \mathrm{L}$ of the extraction buffer was added (2.0\% CTAB, $1.4 \mathrm{M} \mathrm{NaCl}, 0.1 \mathrm{M}$ Tris $\mathrm{HCl}$ at $\mathrm{pH} 8.0,20 \mathrm{mM}$ EDTA, $0.4 \%$ 2-mercaptoethanol, 1.0\% PVP and ultra-pure water q.s.) at $65{ }^{\circ} \mathrm{C}$. The samples were incubated in a water bath at $65^{\circ} \mathrm{C}$ for 45 minutes, being homogenized every 15 minutes. After this period, $700 \mu \mathrm{L}$ of chloroform:isoamyl alcohol (24:1) were added to the samples. The material was gently homogenized and then centrifuged for 10 minutes at $10,000 \mathrm{rpm}$ (in VS-15000c FNII Micro High-Speed Centrifuge). Immediately after, the supernatant was collected.

For better purification of the material, the extraction steps with chloroform:isoamyl alcohol were repeated. $400 \mu \mathrm{L}$ of cooled isopropyl alcohol, which is equivalent to approximately $2 / 3$ of the collected volume, were added to the supernatant. The samples were incubated at $-20^{\circ} \mathrm{C}$ for 20 minutes and then centrifuged for 10 minutes at $12,000 \mathrm{rpm}$. The precipitate was resuspended in $600 \mu \mathrm{L}$ of TE buffer $(10 \mathrm{mM}$ Tris-HCl, $\mathrm{pH} 8.0,1 \mathrm{mM}$ EDTA), with addition of $200 \mu \mathrm{L}$ of $7.5 \mathrm{M}$ ammonium acetate, and the solution was incubated in ice for 15 minutes.

After this period, the samples were centrifuged for 15 minutes at $12,000 \mathrm{rpm}$. The supernatant was recovered and $800 \mu \mathrm{L}$ of absolute ethanol were added. The samples were incubated for one hour at $-20{ }^{\circ} \mathrm{C}$ and centrifuged for 10 minutes at $12,000 \mathrm{rpm}$. Then, the precipitate was washed with $500 \mu \mathrm{L}$ of $70 \%$ ethanol (v/v), centrifuged for 5 minutes at $12,000 \mathrm{rpm}$ and dried at room temperature. The precipitate was resuspended in TE buffer containing $1 \mu \mathrm{L}$ of RNase $(10 \mathrm{mg} / \mathrm{mL})$, and the samples were incubated in a water bath at $37^{\circ} \mathrm{C}$ for one hour. The samples were stored in a freezer at $-20^{\circ} \mathrm{C}$ until the time of use. 


\section{Quantification of genomic DNA}

To evaluate the quality and quantity of the extracted DNA, $3 \mu \mathrm{L}$ of DNA were added to $5 \mu \mathrm{L}$ of staining solution ( $30 \%$ glycerol and $0.25 \%$ bromophenol blue). Then, the samples were applied in $0.8 \%$ agarose gel, stained with ethidium bromide $\left(0.5 \mathrm{mg} . \mathrm{mL}^{-1}\right)$ and subjected to electrophoresis for approximately one hour and twenty minutes at $80 \mathrm{~V}$. The amount of DNA was evaluated by comparative analysis with a DNA of known concentration, DNA lambda (Invitrogen, Carlsbad, CA, USA). In order to perform the amplification reactions, the samples were diluted in TE buffer to adjust their concentration at $5 \mathrm{ng} / \mu \mathrm{L}^{-1}$.

\section{Amplification of genomic DNA with TRAP primers}

Seventeen fixed markers (Table 2) were combined with six arbitrary markers (Table 3 ), resulting in 102 combinations. Of these, 44 combinations with best amplification pattern were selected. The fixed primers were developed for the fatty acid synthesis metabolic pathway for castor bean crop.

Table 2. Characterization of fixed primers (TRAPs) used in the genotyping of 40 elite strains of castor bean.

\begin{tabular}{llccl}
\hline Primer & Sequence (5'-3') & \%GC & GenBank number & Gene/process \\
\hline TRAP12 & GACACCTTTGTTGCCATCG & 52.63 & RCOM_0040840 & Super família LPLAT \\
TRAP13 & ATCCCCAACAAGCACAACA & 47.37 & RCOM_0138550 & Super família Ferritina \\
TRAP14 & TTTCCTTGCTGCCTCTGTG & 52.63 & RCOM_0251360 & Super família Ferritina \\
TRAP15 & CCGTGATTCTGGTGGTGAG & 57.89 & RCOM_0612610 & Super família PLN \\
TRAP16 & TTACAACTGCGGCATCTCC & 52.63 & RCOM_0724080 & Super família PLN \\
TRAP17 & TCCATCCCTTTCCATCCTC & 52.63 & RCOM_0853360 & Super família LPLAT \\
TRAP18 & TGGCATTTGCTTCCTTTGA & 42.11 & RCOM_0893800 & SubfamiliaPLA2 \\
TRAP19 & AATGCCAGCACCTACACCA & 52.63 & RCOM_0900600 & Super família PAP2 \\
TRAP20 & TTATCTTGGGAGGGGCTTG & 52.63 & RCOM_0925410 & Super família PLN \\
TRAP21 & ATCCTTCCAGGCAATCCAC & 52.63 & RCOM_1076810 & Super família Ferritina \\
TRAP22 & CACTCGCCTGTTCAGCACT & 57.89 & RCOM_1081890 & Super família PLN \\
TRAP23 & AGCAAGCCGCACCTAAGAT & 52.63 & RCOM_1403260 & Super família RVT \\
TRAP24 & GTCCAAGCAAAAGCCACCT & 52.63 & RCOM_1431520 & Super família PLN \\
TRAP25 & CCACCAATCCAACGCATAG & 52.63 & RCOM_1464650 & Super família PLN \\
TRAP26 & TTCATCTCCCTTGCCTTCC & 52.63 & RCOM_1502140 & Super família Oleosina \\
TRAP27 & CGAAATCCTCCTGCTCCTC & 52.63 & RCOM_1593790 & Super família LPLAT \\
TRAP28 & GCCACCATCTTCACCACAG & 57.89 & RCOM_1712710 & Super família FABZ \\
\hline
\end{tabular}

Table 3. Arbitrary primers used in the genotyping of 40 elite castor bean strains.

\begin{tabular}{ll}
\hline Name & Nucleotide sequence (3'-5') \\
\hline Arb1 & GACTGCGTACGAATTGAC \\
Arb2 & GACTGCGTACGAATTTGA \\
Arb3 & GACTGCGTACGAATTGCA \\
Arb4 & GACTGCGTACGAATTAATT \\
Arb5 & GACTGCGTACGAATTTGCC \\
Arb6 & GACTGCGTACGAATTGACC \\
\hline \hline
\end{tabular}


The fixed and direct primers were developed by Simões et al. (2017). As reverse primer, six arbitrary primers were used according to Li and Quiros (2001) adapted by $\mathrm{Hu}$ and Vick (2003). Arbitrary primers comprise three selective nucleotides at the 3' end, four nucleotides rich in AT (corresponding to intron regions) or GC (corresponding to exon regions) sequences in the central region and 11 random nucleotides at the 5 ' end.

Amplification reactions were performed in a final volume of $15 \mu \mathrm{L}$ containing $1 \mathrm{X}$ buffer (50 mM Tris-HCL, $20 \mathrm{mM} \mathrm{KCL),} 1.0 \mathrm{U}$ of Taq DNA Polymerase (Invitrogen, Brazil); $2.0 \mathrm{mM}$ of $\mathrm{MgCl}_{2} ; 0.2 \mathrm{mM}$ of dNTP (Invitrogen, Brazil); $0.2 \mathrm{uM}$ of primers (IDT) and $10 \mathrm{ng}$ of DNA. (2017).

Amplifications were performed in a touch-up scheme according to Simões et al.

Electrophoresis was performed in $4 \%$ agarose gel, stained with ethidium bromide $\left(0.5 \mathrm{mg} . \mathrm{mL}^{-1}\right)$. The amplified products were visualized by means of transilluminator and photo-documented in a Kodak Science digital system. Fragment size was estimated by visual comparison with Ladder $100 \mathrm{pb}$ (Invitrogen, Brazil).

\section{Data analysis}

The percentages of seed oil content of the 40 elite castor bean strains were subjected to $\mathrm{F}$ test and Scott-Knott means comparison test at 1\% probability level.

Genetic dissimilarity was estimated by the genotyping of elite strains, by trap markers, together with the means for the seed oil content (SOC) trait. For genotyping, the data were computed as absence (0) and presence (1) of bands in the photographed gels, because it is a dominant marker (TRAP).

The algorithm of Gower (1971) was used to determine the dissimilarity between elite strains. The hierarchical clusters of elite strains were obtained by the UPGMA (Unweighted Pair-Group Method with Arithmetic Averages) method. All results were obtained through the computational resources of the programs: R (R Core Team, 2019) and Genes (Cruz, 2013).

The dendrogram was constructed using MEGA 5 software (Tamura et al. 2011) and the number of clusters was defined using the NbClust package of $R$ (Charrad et al., 2014) using the pseudo- $\mathrm{t}^{2}$ criterion, with analyses performed through the statistical program $\mathrm{R}(\mathrm{R}$ Core Team, 2019). PIC (polymorphism information content) was calculated with GENALEX 6.1 software (Peakall and Smouse, 2012).

\section{RESULTS}

The F test was significant for SOC $(\mathrm{p}<0.01)$, demonstrating that at least one of the other strains differed statistically. This result shows that there is variability for SOC among the studied strains.

The means for SOC and the clustering of elite strains are shown in Table 4. The means for SOC ranged from 39.10 (UFRB 36 - Nordestina BRS149 x EBDA MPA 17) to 55.39 (UFRB 209 - EBDA MPA 17 x Sipeal 28) for the studied strains, with formation of ten distinct clusters (Table 4), showing that there is variability for the studied trait. For SOC, the strains UFRB 209, UFRB 214 and UFRB 256 stood out, the first two from the EBDA MPA 17 x Sipeal 28 crosses and the last strain resulting from the hybridization of 
Mirante 10 x Sipeal 28 (cluster a, Table 4), with the highest means, 55.39, 55.13. and 55.07, respectively. It is worth pointing out that the highest means obtained in this study were higher than the commercial standard (48\%) described by Nobre et al. (2012) and also by other authors: 48\% (Severino et al., 2006), 52.72\% (Omari et al., 2015) and 53.73\% (Tomar et al., 2014).

The lowest means for SOC (39.50\% and 39.10\%; Table 4) were close to the value of 39.43\% found by Yusuf et al. (2015) and higher than that found by Imasuen et al. (2014), which was $30.06 \%$.

Table 4. Means for the seed oil content trait in elite castor bean strains.

\begin{tabular}{|c|c|}
\hline UFRB 209 & $55.39 \mathrm{a}$ \\
\hline UFRB 214 & $55.13 \mathrm{a}$ \\
\hline UFRB 256 & $55.07 \mathrm{a}$ \\
\hline UFRB 5 & $54.43 \mathrm{~b}$ \\
\hline UFRB 249 & $54.37 \mathrm{~b}$ \\
\hline UFRB 176 & $54.18 \mathrm{~b}$ \\
\hline UFRB 129 & $54.18 \mathrm{~b}$ \\
\hline UFRB 232 & $53.92 \mathrm{~b}$ \\
\hline UFRB 55 & $53.77 \mathrm{~b}$ \\
\hline UFRB 128 & $53.49 \mathrm{c}$ \\
\hline UFRB 240 & $53.17 \mathrm{c}$ \\
\hline UFRB 183 & $53.12 \mathrm{c}$ \\
\hline UFRB 265 & $53.07 \mathrm{c}$ \\
\hline UFRB 121 & $52.89 \mathrm{c}$ \\
\hline UFRB 198 & $52.89 \mathrm{c}$ \\
\hline UFRB 195 & $52.70 \mathrm{~d}$ \\
\hline UFRB 6 & $52.52 \mathrm{~d}$ \\
\hline UFRB 229 & $52.50 \mathrm{~d}$ \\
\hline UFRB 186 & $52.43 \mathrm{~d}$ \\
\hline UFRB 45 & $52.43 \mathrm{~d}$ \\
\hline UFRB 223 & $52.42 \mathrm{~d}$ \\
\hline UFRB 118 & $52.40 \mathrm{~d}$ \\
\hline UFRB 119 & $52.33 \mathrm{~d}$ \\
\hline UFRB 181 & $52.32 \mathrm{~d}$ \\
\hline UFRB 29 & $52.00 \mathrm{e}$ \\
\hline UFRB 43 & $51.90 \mathrm{e}$ \\
\hline UFRB 67 & $51.69 \mathrm{e}$ \\
\hline UFRB 205 & $51.63 \mathrm{e}$ \\
\hline UFRB 65 & $51.57 \mathrm{e}$ \\
\hline UFRB 259 & $51.50 \mathrm{e}$ \\
\hline UFRB 230 & $51.20 \mathrm{f}$ \\
\hline UFRB 237 & $51.12 \mathrm{f}$ \\
\hline UFRB 231 & $50.82 \mathrm{f}$ \\
\hline UFRB 117 & $50.79 \mathrm{f}$ \\
\hline UFRB 235 & $50.76 \mathrm{f}$ \\
\hline UFRB 250 & $48.29 \mathrm{~g}$ \\
\hline UFRB 252 & $47.29 \mathrm{~h}$ \\
\hline UFRB 144 & $40.10 \mathrm{i}$ \\
\hline UFRB 28 & $39.50 \mathrm{j}$ \\
\hline UFRB 36 & $39.10 \mathrm{j}$ \\
\hline CV (\%) & 1.02 \\
\hline Overall mean & 51.51 \\
\hline
\end{tabular}


TRAP primers were efficient in the amplification of the genomic DNA of castor bean, corroborating the results obtained by Simões et al. (2017).The high means and wide variation of SOC among the elite strains obtained in this study indicate genetic variability for the castor bean breeding program of NBIO-UFRB.

The 44 combinations of TRAP primers used in the genotyping of the 40 elite castor bean strains generated a total of 380 fragments, of which 230 were polymorphic $(61 \%)$. The number of polymorphic fragments generated per combination varied from 2 (Trap17 $\mathrm{x}$ Arb2) to 10 (Trap28 x Arb4), with an average of 5.2 (Table 5). Simões et al. (2017), when using a greater number of combinations of TRAP primers (330), including those used in this study, identified a variation from 2 (TRAP5 + ARB1; TRAP5 + ARB3; TRAP6 + ARB3; TRAP14 + ARB3; TRAP17 + ARB4; TRAP20 + ARB2; TRAP30 + ARB1; TRAP30 + ARB2; TRAP34 + ARB3) to 15 (TRAP22 + ARB6), with an average of 1.22 loci per combination. The mean of 5.2 polymorphic fragments per combination of primers found in the present study was close to the values of 4.8 derived from 70 combinations in castor bean (Simões et al., 2017), higher than 3.04 derived from 27 combinations of TRAP markers in sugarcane (Mirajkar et al., 2017) and lower than 13.30 derived from 12 TRAP combinations also in sugarcane (Creste et al., 2010).

The fragments showed size amplitude ranging from 50 to $2000 \mathrm{bp}$, similar to the amplitudes from 50 to $2072 \mathrm{bp}$ also in castor bean (Simões et al., 2017).

Polymorphism percentage ranged from 100\% for the combinations Trap14 x Arb4, Trap20 x Arb3, Trap25 x Arb4 and Trap28 x Arb4 to 29\% for Trap17 x Arb2 (Table 5). These results show that TRAP markers are efficient in detecting polymorphism in castor bean.

Polymorphism information content (PIC) ranged from 0.09 for the combination Trap 12 x Arb2 to 0.33 for the combinations Trap13 x Arb1, Trap14 x Arb1, Trap22 x Arb1, Trap24 x Arb1 and Trap27 x Arb3, with an average of 0.26 (Table 5). Considering that TRAP markers are dominant, the maximum observable PIC value is 0.50 . Therefore, the closer to this value, the greater the discriminatory power of the primer. Thus, 23 of the TRAP combinations (52\%) showed PIC above 0.26 , being classified as the markers with the highest discrimination power among the genotypes evaluated (Table 5). In studies conducted with castor bean, PIC values ranged from 0.03 to 0.33 , with an average of 0.24 with 70 combinations of TRAP primers (Simões et al., 2017).

The PIC values found in castor bean are comparable to those observed by the TRAP technique for cassava. In cassava, PIC variation was found to be between 0.03 and 0.38 , with an average of 0.23 in 31 TRAP combinations (Carmo et al., 2015). In sugarcane, there was a PIC variation from 0.0 to 0.22 , with an average of 0.11 in 27 TRAP combinations (Mirajkar et al., 2017). Studies conducted with guarana (Paullinia cupana var. sorbilis) found PIC varying from 0.29 to 0.36 , with an average of 0.33 with 5 combinations of TRAP primers (Da Silva et al., 2016).

It is possible to highlight that studies with TRAP markers in other crops were efficient in detecting polymorphism. Mirajkar et al. (2017), when using 27 combinations of TRAP markers in sugarcane, obtained 133 fragments, of which $82(61.65 \%)$ were polymorphic. In studies also with sugarcane, Suman et al. (2012) used 16 combinations of TRAP markers and were able to detect a high level of polymorphism, with 946 fragments, of which 939 (99\%) were polymorphic. Using 40 different combinations of TRAP primers in wheat, Barakat et al. (2013) were able to observe a total of 242 fragments, of which 200 
(82.64\%) were polymorphic. Da Silva et al. (2016) in a study with guarana (P. cupana var. sorbilis) using 5 combinations of TRAP primers identified 136 fragments, of which 108 (79\%) were polymorphic.

Table 5. Combinations of Target Region Amplification Polymorphisms - TRAP primers for the analysis of the castor bean samples.

\begin{tabular}{|c|c|c|c|c|}
\hline \multirow[t]{2}{*}{ Combination } & \multicolumn{2}{|c|}{ No. of fragments } & \multirow[t]{2}{*}{ \%Poly } & \multirow[t]{2}{*}{ PIC } \\
\hline & Total & Poly & & \\
\hline Trap12 x Arb2 & 7 & 4 & 57 & 0.09 \\
\hline Trap12 x Arb3 & 8 & 3 & 38 & 0.30 \\
\hline Trap12 x Arb5 & 9 & 6 & 67 & 0.22 \\
\hline Trap12 x Arb6 & 11 & 10 & 91 & 0.24 \\
\hline Trap13 x Arb1 & 8 & 5 & 63 & 0.33 \\
\hline Trap13 x Arb2 & 9 & 7 & 78 & 0.31 \\
\hline Trap13 x Arb3 & 12 & 5 & 42 & 0.31 \\
\hline Trap13 x Arb4 & 10 & 5 & 50 & 0.24 \\
\hline Trap13 x Arb5 & 12 & 6 & 50 & 0.23 \\
\hline Trap13 x Arb6 & 8 & 3 & 38 & 0.23 \\
\hline Trap14 x Arb1 & 4 & 3 & 75 & 0.33 \\
\hline Trap14 x Arb4 & 3 & 3 & 100 & 0.21 \\
\hline Trap14 x Arb6 & 8 & 5 & 63 & 0.27 \\
\hline Trap15 x Arb2 & 7 & 6 & 86 & 0.27 \\
\hline Trap 15 x Arb5 & 13 & 4 & 31 & 0.18 \\
\hline Trap16 x Arb2 & 9 & 4 & 44 & 0.14 \\
\hline Trap16 x Arb3 & 8 & 3 & 38 & 0.28 \\
\hline Trap16 x Arb4 & 8 & 4 & 50 & 0.22 \\
\hline Trap17 x Arb2 & 7 & 2 & 29 & 0.24 \\
\hline Trap17 x Arb6 & 6 & 5 & 83 & 0.32 \\
\hline Trap18 x Arb2 & 7 & 3 & 43 & 0.25 \\
\hline Trap18 x Arb3 & 6 & 4 & 67 & 0.27 \\
\hline Trap19 x Arb3 & 9 & 8 & 89 & 0.21 \\
\hline Trap19 x Arb5 & 9 & 3 & 33 & 0.29 \\
\hline Trap20 x Arb1 & 7 & 4 & 57 & 0.25 \\
\hline Trap20 x Arb3 & 6 & 6 & 100 & 0.25 \\
\hline Trap20 x Arb4 & 4 & 2 & 50 & 0.26 \\
\hline Trap21 x Arb2 & 7 & 6 & 86 & 0.22 \\
\hline Trap21 x Arb5 & 9 & 7 & 78 & 0.29 \\
\hline Trap22 x Arb1 & 10 & 7 & 70 & 0.33 \\
\hline Trap22 x Arb6 & 15 & 5 & 33 & 0.31 \\
\hline Trap23 x Arb2 & 6 & 4 & 67 & 0.24 \\
\hline Trap23 x Arb3 & 10 & 5 & 50 & 0.20 \\
\hline Trap24 x Arb1 & 12 & 4 & 33 & 0.33 \\
\hline Trap24 x Arb5 & 10 & 5 & 50 & 0.27 \\
\hline Trap25 x Arb1 & 11 & 5 & 45 & 0.18 \\
\hline Trap 25 x Arb4 & 8 & 8 & 100 & 0.29 \\
\hline Trap26 x Arb2 & 7 & 6 & 86 & 0.27 \\
\hline Trap26 x Arb4 & 7 & 3 & 43 & 0.32 \\
\hline Trap27 x Arb1 & 12 & 6 & 50 & 0.32 \\
\hline Trap27 x Arb2 & 10 & 9 & 90 & 0.20 \\
\hline Trap27 x Arb3 & 10 & 8 & 80 & 0.33 \\
\hline Trap28 x Arb2 & 11 & 9 & 82 & 0.31 \\
\hline Trap28 x Arb4 & 10 & 10 & 100 & 0.28 \\
\hline Means & 8.6 & 5.2 & & 0.26 \\
\hline
\end{tabular}

* Poly= Polymorphism; PIC $=$ Polymorphism information content 
Allan et al. (2008) observed low levels of polymorphism, through AFLP markers, for castor bean. Contrary to this result, Pecina-Quintero et al. (2013) observed that 50\% of the AFLP markers studied were polymorphic, detecting high levels of genetic divergence (71\%) for castor bean, which corroborates the results found by Gajera et al. (2010) with RAPD markers and polymorphism of $80.2 \%$. These results are partly due to a selection of primers with the ability to amplify polymorphic fragments.

From the joint evaluation for SOC and TRAP markers, a genetic distance variation from 0.19 to 0.97 , with an average of 0.47 , was obtained among the elite strains studied. The most genetically similar elite strains were UFRB231 and UFRB240 (genetic distance of 0.19). It is worth highlighting that the strains UFRB 231 and UFRB240 came from the same crosses (EBDA MPA 17 x Sipeal 28), showing a high degree of kinship. However, these strains have different percentages of oil content: UFRB231 with 50.82 (cluster $f$ ) and UFRB240 with 53.17 (cluster c).

The most dissimilar strains were UFRB117 in comparison to UFRB29, UFRB45, UFRB128, UFRB230 and UFRB240 (genetic distance of 0.97). It is important to note that the most genetically distant strains were obtained from the crosses between different parents (Paraguaçu BRS188 x EBDA MPA 17, Nordestina BRS149 x EBDA MPA 17 and EBDA MPA $17 \mathrm{x}$ Sipeal 28). These results show that there is genetic variability among elite strains and also high genetic dissimilarity, an important factor for the genetic improvement of the species.

The strains UFRB117 x UFRB29, UFRB45, UFRB128, UFRB230 and UFRB240 showed percentage values for the SOC trait of 50.79 (cluster f), 52.00 (cluster e), 52.43 (cluster d), 53.49 (cluster c), 51.20 (cluster f) and 53.17 (cluster c), respectively. The SOC means can be observed in Table 4 . The other strains were distributed in intermediate clusters.

Goodarzi et al. (2015), when evaluating the genetic divergence between 12 castor bean genotypes, using the dominant marker ISSR, obtained a minimum genetic distance of 0.20 and a maximum of 0.56, a result lower than that found in the present study. On the contrary, Kallamadi et al. (2015) observed a variation in genetic distance from 0.47 to 0.91 among 31 castor bean accessions by RAPD and ISSR markers. Also, high values of genetic distance were observed by: Kanti et al. (2014), ranging from 0.65 to 0.90 among 51 castor accessions by means of 35 SSR markers; Gajera et al. (2010), ranging from 0.53 to 0.91 among 22 castor bean genotypes with RAPD markers; and Thatikunta et al. (2016), ranging from 0.24 to 0.83 among 27 castor bean accessions with SSR markers.

The dendrogram shows the formation of 3 distinct clusters: C1= UFRB235, UFRB237, UFRB230, UFRB223, UFRB229, UFRB232, UFRB249, UFRB176, UFRB183, UFRB205, UFRB252, UFRB67, UFRB181, UFRB118, UFRB121, UFRB129, UFRB119, UFRB128, UFRB28, UFRB209, UFRB265, UFRB5, UFRB6, UFRB256 and UFRB259; $\mathbf{C 2}=$ UFRB65, UFRB144, UFRB36, UFRB250, UFRB45, UFRB55, UFRB29, UFRB43, UFRB231, UFRB240, UFRB186, UFRB195 and UFRB198; C3= UFRB117 and UFRB214. Cluster 1 represents $63 \%$ of elite strains, cluster 2 represents $33 \%$ and cluster 3 represents $5 \%$ (Figure 1). It is worth pointing out that, despite the formation of only 3 clusters, there were high values of genetic distance (0.97), with an average of 0.47 . In addition, it is possible to observe the formation of several subclusters (Figure 1).

Cluster 1 was the most numerous, being divided into eleven subclusters. A total of 92\% of the elite strains in cluster 1 came from crosses involving the parent EBDA MPA 17. 
Cluster 2 was divided into six subclusters, and 54\% of the elite strains grouped came from crosses between the parents Nordestina BRS149 and EBDA MPA 17. Cluster 3 had only one subcluster formed by elite strains from crosses with the parent EBDA MPA 17.

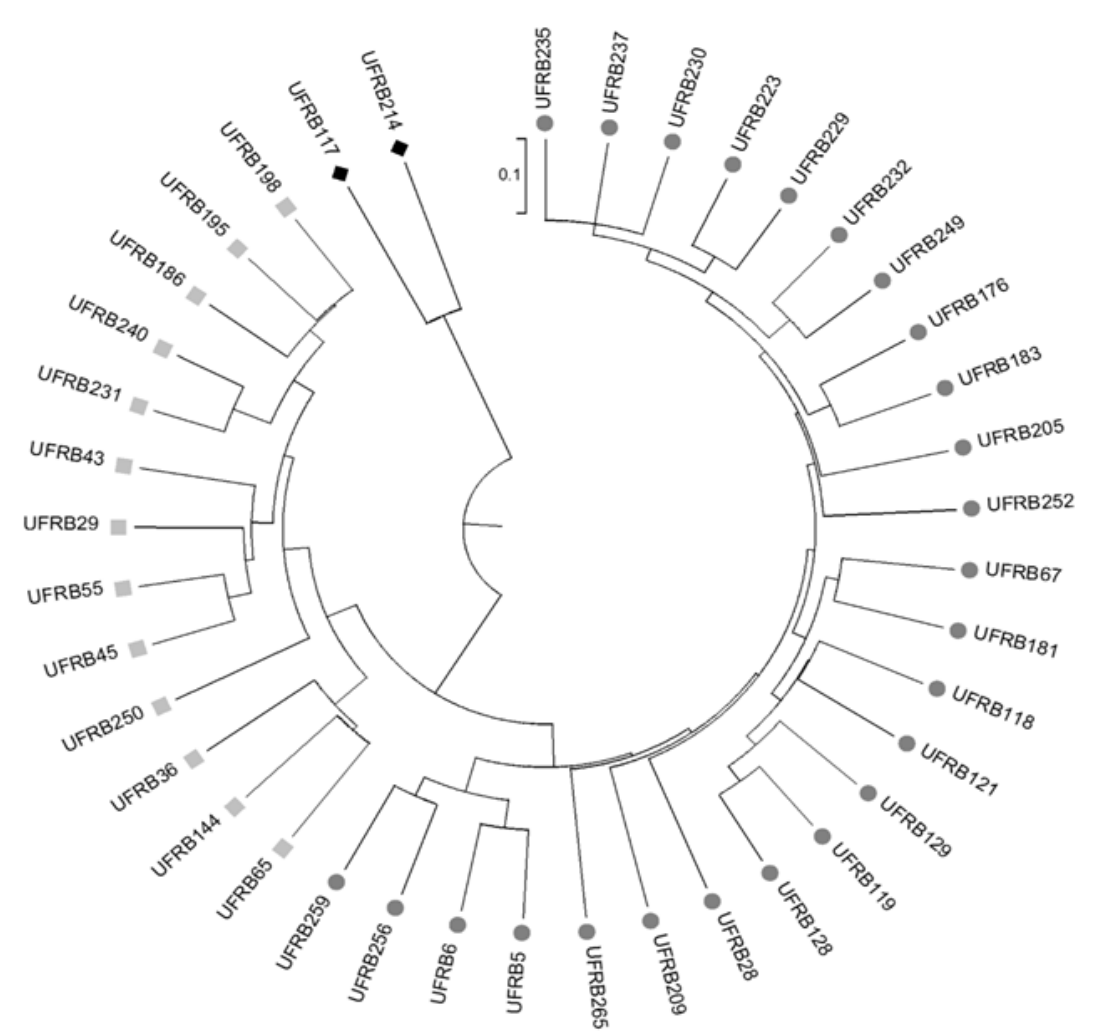

Figure 1. Genetic dissimilarity among 40 elite strains of the active germplasm bank - AGB of castor bean. • cluster 1; cluster 2 and cluster 3. Dendrogram constructed from 44 combinations of TRAP markers using the Gower index.

These results are similar to those of the studies conducted by Kanti et al. (2014) and Gajera et al. (2015), who obtained the formation of three clusters. Kanti et al. (2014) evaluated 51 castor bean genotypes using 35 SSR primers, and Gajera et al. (2010) evaluated 22 genotypes with RAPD and ISSR markers. Goodarzi et al. (2015) found 4 clusters in 12 castor bean accessions using ISSR markers, and Thatikunta et al. (2016) found only 2 clusters in 27 castor bean accessions using SSR markers. In the latter, cluster 1 was responsible for containing $96.3 \%$ of the accessions analyzed.

It is important to note that the strains with the highest means of SOC, UFRB 209, UFRB 214 and UFRB 256 (Table 4), were grouped separately in the joint analysis. UFRB 214 belongs to cluster 3, while the strains UFRB 209 and UFRB 256 belong to cluster 1 (Figure 1), showing genetic dissimilarity. The strains UFRB 209 and UFRB 214 came from crosses with the same parents (EBDA MPA 17 x Sipeal 28), while UFRB 256 came from crosses between the parents Mirante 10 and Sipeal 28. This observation includes the other 
strains that had equal SOC values, but were separated in the joint analysis (Figure 1). This result is favorable to the castor bean breeding program, because these strains, despite having similar SOC means, are diverge in joint evaluation with respect to molecular markers and their genetic constitution and may be released as distinct cultivars in the future.

The vast majority of studies, in general, use qualitative and quantitative descriptors separately, since the latter ones are analyzed only by descriptive statistics. This can segment inferences and conclusions about genetic divergence, often limiting its later use, for instance in breeding programs. Joint analysis of qualitative and quantitative data through the Gower algorithm can provide a better understanding about the characteristics considered and, mainly, more judicious and effective conclusions from the statistical point of view about the genetic relationship.

\section{CONCLUSIONS}

The TRAP markers developed in this study based on seed oil content are polymorphic and suitable for studies on genetic variability in castor bean. Joint analysis using SOC means and TRAP markers was efficient in detecting genetic variability among elite strains. There is genetic divergence among the elite strains with potential to be used in the castor bean breeding program.

\section{ACKNOWLEDGMENTS}

This study was supported by the Coordenação de Aperfeiçoamento de Pessoal de Nível Superior (CAPES), Petrobrás Biocombustível and the Agência Nacional de Petróleo, Gas Natural e Biocombustível (ANP).

\section{CONFLICTS OF INTEREST}

The authors declare no conflict of interest.

\section{REFERENCES}

Allan G, Williams A, Rabinowicz PD, Chan AP, et al. (2008). Worldwide genotyping of castor bean germplasm (Ricinus communis L.) using AFLPs and SSRs. Genet. Resour. Crop. Ev. 55: 365-378. http://dx.doi.org/ 10.1007/s10722007-9244-3.

Barakat MN, Al-Doss AA, Elshafei AA, Ghazy AI, et al. (2013). Assessment of genetic diversity among wheat doubled haploid plants using TRAP markers and morpho-agronomic traits. Aust. J. Crop. Sci. 7: 104 -111.

Carmo CD, Santos DB, Alves LB, Oliveira GAF, et al. (2015). Development of TRAP (Target Region Amplification Polymorphism) as New Tool for Molecular Genetic Analysis in Cassava. Plant Mol. Bio. Rep. 33: $1953-1966$. http://dx.doi.org/ 10,1007 / s11105-015-0887-5.

Cavalcanti MLF, Fernandes PD, Gheyi HR, Barros Júnior G, et al. (2005). Índices ecofisiológicos da mamoneira sob estresse salino. Rev. Bras. Eng. Agríc. Ambiental. 9: 66-70.

Charrad M, Ghazzali N, Boiteau V and Niknafs A (2014). NbClust: An R package for determining the relevant number of clusters in a data set. J. Stat. Softw. 61: 1-36. https://doi.org/10.18637/jss.v061.i06.

Companhia Nacional de Abastecimento (CONAB ) (2017). Acompanhamento da safra de grãos. Décimo levantamento Safra 2016/2017. http://www.conab.gov.br/conteudos.php? $\mathrm{a}=1253 \& \mathrm{t}=1>$. ( (accessed on October 18, 2019).

Creste S, Sansoli DM, Tardiani ACS, Silva DN, et al. (2010). Comparison of AFLP, TRAP and SSRs in the estimation of genetic relationships in sugarcane. Sugar Tech. 12: 150-154. http://dx.doi.org/10.1007/s12355-010-0029-1.

Crossa J and Franco J (2004). Statistical methods for classifying genotypes. Euphytica. 137: 19-37. http://dx.doi.org/10.1023/B:EUPH.0000040500.86428.e8. 
Cruz CD (2013). GENES - a software package for analysis in experimental statistics and quantitative genetics. Acta Sci. Agron. 35: 271-276. https://doi.org/10.4025/actasciagron.v35i3.21251.

Cunha GHM, Rocha U and Oliveira AB (2017). Economia da mamona: uma visão do mercado brasileira no início do século XXI. CCCSS. 1-25.

Da Silva EF, de Sousa SB, da Silva GF, Sousa NR, et al. (2016). TRAP and SRAP markers to find genetic variability in complex polyploid Paullinia cupana var. sorbilis. Plant Gene. 6: 43-47. http://dx.doi.org/ 10.1016/j.plgene.2016.03.005

Doyle JJ and Doyle JL (1990). A rapid total DNA preparation procedure for fresh plant tissue. Focus. 12: 13-15.

Food and Agriculture organization of the United Nations (FAOSTAT) (2017). Castor Oil Seeds. Production and trade. Castor beans http://www.faostat.fao.org. (accessed on October 18, 2019).

Gajera BB, Kumar N, Singh AS, Punvar BS, et al. (2010). Assessment of genetic diversity in castor (Ricinus communis L.) using RAPD and ISSR markers. Ind. Crop Prod. 32: 491-498. http://dx.doi.org/10.1016/j.indcrop.2010.06.021.

Gonçalves LSA, Rodrigues R, Amaral Junior AT, Karasawa M, et al. (2008). Comparison of multivariate statistical algorithms to cluster tomato heirloom accessions. Genet. Mol. Res. 7: 1289-1297. http://dx.doi.org/ 10.4238/vol74gmr526.

Goodarzi F, Darvishzadeh R and Hassani A (2015). Genetic analysis of castor (Ricinus communis L.) using ISSR markers. J. Plant Mol. Breed. 3: 18-34. http://dx.doi.org/ 10.22058/jpmb.2015.14130.

Gower JC and et al. (1971). A general coefficient of similarity and some of its properties. Biometrics. 27: 857-874. http://dx.doi.org/10.2307/2528823.

$\mathrm{Hu} \mathrm{J}$ and Vick BA (2003). Target region amplification polymorphism: a novel marker technique for plant genotyping. Plant Mol. Biol. Rep. 2: 289-294. http://dx.doi.org/ 10,1007 / BF02772804.

Imasuen A, Inegbedion F, Erhabor C and Osuide M (2014). Isolation and characterization of Castor Seed oil and its utilization potential in the production of polyurethane foam. Walailak J. Sci. \& Tech. 11: 421- 427. http://dx.doi.org/ 10.2004/wjst.v11i5.668.

Instituto Brasileiro de Geografia e Estatística. Indicadores (IBGE) (2017) - Estatística da produção agrícola. 74.

Kallamadi PR, Nadigatla VPRGR and Mulpuri S (2015). Molecular diversity in castor (Ricinus communis L.). Ind. Crops Prod. 66: 271-281.http://dx.doi.org/10.1016/j.indcrop.2014.12.061.

Kanti M, Anjani K and VenkatRamya K (2014). Molecular Diversity in Castor Germplasm Collection Originated from North-Eastern Hill Province of India. IJRSI. 1(6): 1-6.

Li G and Quiros CF (2001). Sequence-related amplified polymorphism (SRAP), a new marker system based on a simple PCR reaction: its application to mapping and gene tagging in Brassica. Theor. Appl. genet.103: 455-461.

Machado CF, Souza FVD, Ledo CAS and Cabral JRS (2011). Cluster analysis using quantitative, qualitative and molecular traits for the study of the genetic diversity in pineapple genotypes. Acta Hortic. 902: 159-162.

Machado CF, Jesus FN and Ledo CAS (2015). Divergência genética de acessos de maracujá utilizando descritores quantitativos e qualitativos. Rev. Bras. Frutic. 37: 442-449. http://dx.doi.org/10.1590/0100-2945-110/14.

Madalena LCS, Oliveira AF, Santos RF, Rosseto RE, et al. (2017) . Uma revisão do uso do óleo de rícino proveniente da Mamona (Ricinus communis L.), em diversos setores industriais e combustíveis. Acta Iguazu 6: 01-12.

Mason NWH, Mouillot D, Lee WG and Wilson JB (2005). Functional richness, functional evenness and functional divergence: the primary components of functional diversity. Oikos. 111: 112-118. http://dx.doi.org/10.1111/j.00301299.2005.13886.x.

Mirajkar SJ, Rai AN, Vaidya ER, Moharil MP, et al. (2017). TRAP and SRAP molecular marker based profiling of radiation induced mutants of sugarcane (Saccharum officinarum L.). Plant Gene. 9: 64-70. http://dx.doi.org//10.1016/j.plgene.2017.01.002.

Nobre RG, Lima GS, Gheyi HR, Medeiros EP, et al. (2012). Teor de óleo e produtividade da mamoneira de acordo com a adubação nitrogenada e irrigação com água salina. Pesq. Agropec. Bras. 47: 991-999. http://dx.doi.org/10.1590/S0100-204X2012000700016.

Omari A, Mgani QA and Mubofu EB (2015). Fatty Acid Profile and Physico-Chemical Parameters of Castor Oils in Tanzania. Green Sustain. Chem. 5: 154-163. http://dx.doi.org/10.4236/gsc.2015.54019.

Pecina-Quintero V, Anaya-López JL, Núnez-Colín CA, Zamarripa-Colmenero A, et al. (2013). Assessing the genetic diversity of castor bean from Chiapas, México using SSR and AFLP markers. Ind. Crops Prod. 41: 134-143. https://doi.org/10.1016/j.indcrop.2012.04.033.

Peakall R and Smouse PE (2012). GenAlEx 6.5: genetic analysis in Excel. Population genetic software for teaching and research--an update. Bioinformatics. 28: 2537-2539. https://doi.org/10.1093/bioinformatics/bts460

Pestana-Caldas CN, Silva AS, Machado EL, de Souza DR, et al. (2016). Genetic divergence through joint analysis of morphoagronomic and molecular characters in accessions of Jatropha curcas. Genet. Mol. Res. 15. http://dx.doi.org/10.4238/gmr.15048385.

Poczai P, Varga I, Laos M, Cseh A, et al. (2013). Advances in plant gene-targeted and functional markers: a review. Plant Methods. 9: 6. http://dx.doi.org/10.1186/1746-4811-9-6.

R Core Team (2019). R: A language and environment for statistical computing. R Foundation for Statistical Computing, Vienna, Austria. Available at [http://www.R-project.org]. Accessed April 10, 2020. 
Ramos HCC, Pereira MG, Gonçalves LSA, Berilli AP, et al. (2012). Multivariate analysis to determine the genetic distance among backcross papaya (Carica papaya) progenies. Genet. Mol. Res. 11: 1280-1295. http://dx.doi.org/10.4238/2012.May.14.2.

Severino LS, Ferreira GB, Moraes CR de A, Gondim TM de S, et al. (2006). Produtividade e crescimento da mamoneira em resposta à adubação orgânica e mineral. Pesq. Agropec. Bras. 41: 879-882. http://dx.doi.org/ 10.1590/S0100204X200600050002.

Silva AR, Silva SA, Santos LA, Souza DR, et al. (2017). Genetic divergence among castor bean lines and parental strains using ward's method based on morpho-agronomic descriptors. Acta Sci. Agron. 39: 307-313. http://dx.doi.org/10.4025/actasciagron.v39i3.32504.

Simões KS, Silva SA, Machado EL and Silva MS (2017). Genetic divergence in elite castor bean lineages based on TRAP markers. Genet. Mol. Res. 16: gmr16039776.

Souza GA de, Carvalho MRO, Martins ER, Guedes RNC, et al. (2008). Diversidade genética estimada com marcadores ISSR em populações brasileiras de Zabrotes subfasciatus. Pesq. Agropec. Bras. 43: 843-849. http://dx.doi.org/ 10.1590/S0100-204X2008000700008.

Suman A, Ali K, Arro J, Parco AS, et al. (2012). Molecular Diversity Among Members of the Saccharum Complex Assessed Using TRAP Markers Based on Lignin-Related Genes. Bioenerg. Res. 5: 197-205. http://dx.doi.org/10.1007/ s12155-011-9123-9.

Tamura K, Peterson D, Peterson N, Stecher G, et al. (2011). MEGA5: Molecular Evolutionary Genetics Analysis using Maximum Likelihood, Evolutionary Distance, and Maximum Parsimony Methods. Mol. Biol. Evol. 28: 2731-2739. http://dx.doi.org/ $10.1093 / \mathrm{molbev} / \mathrm{msr} 121$.

Thatikunta R, Sankar AS, Sreelakshmi J, Palle G, et al. (2016). Utilization of in silico EST-SSR markers for diversity studies in castor (Ricinus communis L.). Physiol. Mol. Biol. Plants. 22: 535-545. http://dx.doi.org/ 10.1007/s12298016-0367-x.

Tomar RS, Parakhia MV, Kavani RH, Dobariya KL, et al. (2014). Characterization of castor (Ricinus communis L.) genotypes using different markers. Res. J. Biotechnol. 9: 6-13.

Torres EA, Chirinos HD, Alves CT, Santos DC, et al. (2006). Biodiesel: o combustível para o novo século. Bahia Análise e Dados. 89-95.

Yusuf AK, Mama PP, Ahmd AS and Agunw U (2015). Extraction and characterization of castor seed oil from wild Ricinus communis Linn. Int J Sci Environ 4: 1392-1404. 